\title{
Última edição da Polímeros publicada em Português
}

\section{Last volume of Polímeros published in Portuguese}

Há 26 anos a Polímeros iniciou seus primeiros passos publicando artigos escritos apenas na língua portuguesa. Depois de vários anos resolveu expandir seus horizontes publicando também artigos escritos em espanhol e inglês. Artigos escritos nos três idiomas eram publicados sem nenhuma preferência ou prioridade. Mais recentemente, seguindo o exemplo das grandes revistas científicas internacionais o Comitê Editorial apoiado pelo Conselho Editorial decidiu por publicar artigos escritos apenas na língua inglesa. Tal decisão se baseou no interesse dos autores em ter suas publicações lidas e citadas também pela comunidade internacional. Isto claramente aumenta a divulgação das ideias e por consequência o número de citações. Mesmo tendo tomado tal decisão tínhamos consciência que ainda tínhamos muitos artigos escritos em português em processo de análise, que muitos deles, devido a sua ótima qualidade técnico-científica foram aprovados. Desta forma decidimos agrupá-los todos nesta que será a última edição da revista Polímeros publicada exclusivamente em português. Inclusive esta é a razão deste editorial ter sido escrito nesta mesma língua. Aproveite estes 16 artigos, leia-os com uma ponta de nostalgia dos bons tempos que não éramos pressionados a atingir o mundo com nossas publicações, apenas o público brasileiro já nos bastava!

Sebastião V. Canevarolo Editor-in-Chief 